\title{
МЕТОДИЧНІ ОСНОВИ ФОРМУВАННЯ СЦЕНІЧНО-ОБРАЗНОЇ КУЛЬТУРИ МАЙБУТНЬОГО ВЧИТЕЛЯ МУЗИЧНОГО МИСТЕЦТВА У ПРОЦЕСІ ВОКАЛЬНОї ПІДГОТОВКИ
}

\section{Н. Л. Косінська}

В статті висвітлено методичні основи формування сценічно-образної культури майбутніх учителів музичного мистеитва в процесі вокальної підготовки. Проаналізовано стан досліджуваної проблеми в педагогічній теорії та практиці, визначено мету, завдання, розкрито сутність основних форм та методів в навчальному процесі та визначено їх вплив на фахове зростання майбутніх вчителів музичного мистеитвва.

Метою статті є визначення і обтрунтування методичних основ (змісту, форм і методів) формування сценічно-образної культури майбутніх учителів музичного мистецтвв в процесі вокальної підготовки.

Дослідження показало, що впровадження певних форм та методів у навчальний прочес сприяє поглибленню методичних знань, оптимізаџії навчального процесу, розвитку міжпредметних зв'язків та якісній підготовиі майбутніх учителів. Зазначені форми та методи дозволяють систематично, послідовно вдосконалювати знання, вміння (інтерпретацію - акторську, вокальну), здійснювати рефлексивне оцінювання власної сценічної культури.

Володіння сиенічно-образною культурою, яка є складовою професійної культури вчителя музичного мистецтвв, дає змогу здійснювати світоглядний, естетичний, етичний, творчий розвиток дитини на основі інтерпретації художніх образів, їх вокального оформлення та сиенічного вираження. Саме тому має відбуватися трансформація змісту, форм та методів підготовки вчителя музичного мистецтва $з$ урахуванням методичних основ професійної, зокрема, вокальної підготовки майбутнього педагогамузиканта, який покликаний ретранслювати мистецько-культурні иінності в освітньо-культурному середовищі

Ключові слова: зміст, методи, форми, сиенічно-образна культура, майбутній вчитель музичного мистецтвва, вокальна підготовка

Copyright (C) 2019, N. Kosinska. This is an open access article under the CC BY license (http://creativecommons.org/licenses/by/4.0).

\section{1. Вступ}

В сучасній мистецько-педагогічній освіті актуалізується проблема формування окремих важливих професійних якостей майбутнього вчителя музичного мистецтва, з-поміж яких виокремлюється сценічно-образна культура. Означена якість вчителя музики дозволяє залучати учнів до цінностей мистецтва, мистецького досвіду людства і окремого етносу на основі здатності інтерпретувати та сценічно представляти музичні образи, «розкодовувати» художньо-естетичну образність музичних творів у співвіднесенні 3 сучасною дійсністю, естетичними цінностями, етичною парадигмою світосприйняття окремої особистості та філософією суспільного буття сучасності. Саме тому має відбуватися трансформація змісту, методів і форм підготовки вчителя музичного мистецтва 3 урахуванням методичних орієнтирів професійної, зокрема вокальної, підготовки, упровадження авторських методик формування цієї якості майбутнього педагога-музиканта, який покликаний ретранслювати мистецько-культурні цінності в умовах загальноосвітнього закладу.
Володіння сценічно-образною культурою, яка $є$ складовою професійної культури вчителя музики, дозволяє здійснювати світоглядний, естетичний, етичний, творчий розвиток дитини на основі інтерпретації художніх образів, їх вокального оформлення та сценічного вираження. Відповідно виникає необхідність у висвітленні методичних основ формування сценічно-образної культури майбутнього вчителя музичного мистецтва.

\section{2. Літературний огляд}

Робота над визначеною темою статті зумовила необхідність вивчення та аналізування наукової літератури, яка склала теоретичну базу дослідження. У педагогічному дискурсі української і зарубіжної науки наявний спектр досліджень, які дозволяють цілісно проаналізувати методичні основи формування сценічно-образної культури майбутнього вчителя музичного мистецтва, визначити основні форми та методи формування означеної якості у процесі вокальної підготовки.

3 поміж досліджень виокремимо праці науковців, педагогів, у яких: 
- досліджено проблеми професійної підготовки майбутніх учителів музичного мистецтва до вокально-педагогічної діяльності [1];

- обгрунтовано теоретичні аспекти підготовки вчителя музичного мистецтва [2];

- висвітлено та методично схарактеризована технологія “майстер-класу” у методичній підготовці майбутніх учителів музики [3];

- розкрито сутність теоретичних та методичних основ музичної освіти [4];

- проаналізовано підготовку майбутніх учителів до професійної діяльності в процесі навчання у 3BO [5];

- висвітлено проблеми професійної підготовки вчителя мистецьких дисциплін [6] та [7];

- досліджена проблема створення сценічного образу в процесі становлення студентського театру [8];

- висвітлено та схарактеризовано поняття “зміст освіти” [9];

- визначено методологічні аспекти мистецької освіти [10];

- розкрито сутність формування професійної компетентності вчителя, зокрема педагогамузиканта [11];

- розкрито професійну значущість якостей майбутнього вчителя музики [12];

- визначено проблеми формування художньоінтерпретаційних умінь майбутніх учителів музичного мистецтва [13];

- обгрунтовано та розкрито вплив театру на формування професійних компетентностей педагогівмузикантів[14].

Водночас у мистецько-педагогічних джерелах не належно висвітлена проблема обгрунтування методичних основ формування сценічно-образної культури майбутнього вчителя музичного мистецтва.

\section{3. Мета та задачі дослідження}

Метою статті $є$ визначення і обгрунтування методичних основ (змісту, форм і методів) формування сценічно-образної культури майбутніх учителів музичного мистецтва в процесі вокальної підготовки.

Для досягнення мети нами були поставлені такі завдання:

1. Проаналізувати наукову літературу 3 окресленої проблеми за допомогою теоретичних методів дослідження.

2. Схарактеризувати основні форми і методи формування сценічно-образної культури, розкрити їх вплив на фахове зростання майбутніх учителів музичного мистецтва.

\section{4. Методичні основи дослідження}

У результаті аналізу праць 3 проблем мистецької освіти, підготовки вчителя музичного мистецтва, узагальнимо зміст, форми і методи, які доцільно застосовувати у процесі формування професійно значущих якостей майбутнього фахівця.

Найголовнішим завданням, на нашу думку, $є$ оновлення змісту вокальної підготовки 3 урахуванням специфіки формування сценічно-образної культури майбутнього вчителя музичного мистецтва.
Упровадження змістових модулів з метою оновлення змісту вокальної підготовки майбутнього вчителя музичного мистецтва передбачає наповнення проблемним матеріалом 3 питань досвіду формування сценічно-образної культури майбутніх фахівців. У педагогічній теорії зміст освіти розглядається як «обсяг навчальної інформації, засвоєння якої забезпечує особі можливість здобуття освіти і певної кваліфікації, а також обумовлена потребами суспільства система знань, умінь і навичок особи, іiі професійних, світоглядних і громадських якостей, що має бути сформована у процесі навчання з урахуванням перспектив розвитку суспільства, науки, техніки, технологій, культури, мистецтва» [9]. Упровадження змістових модулів з проблем сценічно-образної культури майбутніх учителів музичного мистецтва передбачає поглиблене ознайомлення 3 досвідом національного і світового вокального мистецтва 3 позиції вияву акторської майстерності, імпровізаційних умінь, вокальної техніки тощо.

3 метою обгрунтування методичних основ формування сценічно-образної культури майбутнього вчителя музичного мистецтва нами було відібрано спектр форм і методів, які, на нашу думку, є більш доцільними й ефективними.

3 метою формування мотивації щодо формування сценічно-образної культури майбутніх вчителів музичного мистецтва, їх спрямованості на здійснення художньої, вокальної, сценічної інтерпретації музичних творів, що значно поглиблює ї ціннісні смисли, доцільно використовувати відповідний репертуар. Добір репертуару (народних пісень, авторських музичних творів українських i зарубіжних митців), що мають ціннісний потенціал формування мотивації щодо формування сценічнообразної культури, має відбуватися 3 урахуванням спектру вимог. Найбільш значущими з них, на думку автора, є такі, як: художній рівень творів відносно музики і тексту; відповідність художньовиконавським можливостям конкретної особистості; сприйняття творів 3 огляду на вік учасників; зіставлення конкретного твору з іншими творами; виховні функції творів; вибір творів для повсякденної роботи i на перспективу, для концертного виступу(тематичного, для звітного концерту) [11]. На нашу думку, у процесі добору репертуару з метою формування сценічно-образної культури необхідно враховувати саме ціннісно-смислове наповнення музичних творів, можливості для реалізації їх етикоестетичного потенціалу під час вокального виконання і сценічної інтерпретації. Відібраний музичний матеріал повинен бути благодатним тлом для розвитку артистичності, умінь перевтілюватися під час вокального виконання музики різних стилів і жанрів, мати високий рівень ціннісно-смислового насичення тексту.

Вагомим ресурсом для формування ціннісномотиваційної спрямованості на відбір відеотеки зразків виконання вокальних творів 3 урахуванням рівня акторської майстерності відомих особистостей або фрагментів уроків музики, які демонструють вчителі-практики, на широкий загал через посередництво інтернет-ресурсів. Вибір цієї форми фор- 
мування сценічно-образної культури зумовлений загальною тенденцією упровадження інформаційнокомунікативних технологій, мережевих засобів, що зумовлено тенденцією комп'ютеризації навчання, зокрема процесу підготовки педагогічних кадрів. Так, науковець акцентує увагу на тому, що виникає «необхідність уведення інформаційно-комунікаційних технологій у музичне навчання задля його перетворення на високохудожній i високотехнологічний процес», адже «нові програмні засоби, які гнучко поєднують педагогічний інструментарій традиційного навчання музики та можливості комп'ютерних технологій, дозволяють використовувати музичний комп'ютер як професійний інструмент майбутнього фахівця» [10]. Відповідно використання відеотеки у процесі формування сценічнообразної культури майбутнього вчителя музики значно активізує творчий потенціал майбутнього фахівця, дозволяє змоделювати педагогічні ситуації, спроектувати фрагменти уроків 3 музики з урахуванням елементів вокальної і акторської майстерності.

Відповідно на етапі розвитку мотиваційноціннісних орієнтирів у процесі формування сценічнообразної культури майбутніх учителів музичного мистецтва є потреба у використанні методу інтерпретації, що доцільно застосовувати у процесі аналізу художньо-стильового, змістового плану музичних творів. Дослідник здійснення інтерпретації тлумачить як «розуміння змістової сутності музичного твору та втілення розуміння у виконанні; індивідуально-образне тлумачення виконавцем об'єктивної композиторської інформації, що характеризується рисами ідеально-уявного бачення предмету трактування», адже «художня інтерпретація передбачає глибоке проникнення в зміст музичного твору, виявлення ціннісного ставлення до музики, відтворення набутого досвіду в усій його цілісності i $\epsilon$ невід'ємним структурним компонентом досвіду, зокрема, виконавського, вміння, що зумовлюють здатність належно виконувати дії» [13]. У процесі застосування методу інтерпретації 3 метою формування сценічно-образної культури майбутнього вчителя музичного мистецтва доцільно передбачати поетапність декодування художньо-образного наповнення твору, основних прийомів звуковибудовування, художньої природи музичного матеріалу, концентрації уваги на звучанні і свободі виконавського апарату; здійсненні слухового самоконтролю.

3-поміж інтерактивних методів навчання у процесі вокальної підготовки майбутніх учителів музичного мистецтва доцільно застосовувати метод лекції-концерту, яка 3 метою формування сценічнообразної культури дозволяє продемонструвати в дії вокальну й акторську майстерність, спроектувати можливості використання театралізованих елементів під час викладу теоретичного матеріалу, інформаційний матеріал подати більш емоційно, експресивно, що створює ефект запам'ятовування, конструктивної діалогічної взаємодії. На переконання науковиць, «кожна лекція-концерт - це «зустріч-діалог», у якому один ціннісний світ людської особистості розвивається назустріч іншому, взаємодоповнюючи та збагачуючи один одного. Отже, студент має можливість на практиці перевірити результативність діалогової стратегії педагогічної взаємодії, що поступово стає пріоритетною у вітчизняній системі освітніх технологій» [5]. Ця форма проведення занять 3 вокальних дисциплін особливо доцільна у процесі формування сценічно-образної культури майбутніх учителів музичного мистецтва, що дозволяє представити досвід вияву артистизму, вокальної майстерності, елементів сценічної інтерпретації музичних образів, що можливо ретранслювати, індивідуально осмисливши на особистісному рівні, у процесі педагогічної роботи, під час організації виховних заходів, їх музичного супроводу, театрального супроводження тощо. 3 метою вивчення досвіду запропоновано

тематику лекції-концерту 3 фрагментами викладу лекційного (теоретичного) матеріалу та зразками виконання вокальних творів 3 урахуванням сценічної майстерності, полісемантичності музичних образів :

1. «Сценічні образи у творчості зарубіжних $\mathrm{i}$ українських виконавців» (Е. Карузо, М. Ланца, П. Домінго, Л. Паваротті, М. Каллас, С. Крушельницька, Б. Гмиря, Є. Мірошниченко та ін.);

2. Творча спадщина видатних українських композиторів у розвитку сценічної майстерності (на прикладі творів Миколи Лисенка, Платона Майбороди, Олександра Білаша, Володимира Івасюка та ін.)

Ефективною формою формування сценічнообразної культури майбутнього вчителя музичного мистецтва у процесі вокальної підготовки є семінаридискусії, на яким поповнюються знання з проблеми теорії сценічної і вокальної майстерності, водночас активізується творчий потенціал студентів, розвивається здатність до артистичності, імпровізаційності, креативності, формується комунікативна культура, доказовість власної позиції. На переконання вченої, «дискусійні методи навчання допомагають студентам-музикантам ефективно усвідомлювати й засвоювати навчальний матеріал тому, що вони беруть активну участь в обговоренні питання, що обов'язково змушує їх зайняти власну позицію щодо обговорюваної проблеми, а значить, краще запам'ятати необхідні знання. Дискусійні методи допомагають студентам не тільки відстоювати власну точку зору, а й у ході дискусії знайти правильну відповідь або рішення. Такі методи сприяють вмінню аргументовано викладати власні думки, доводити свою точку зору, логічно будувати відповідь» [12]. У межах проведення семінарських занять 3 дисциплін вокальної підготовки доцільно проводити дискусії з проблем сценічної майстерності, акторства у педагогічній професії, імпровізаційності під час викладання музики в шкільній практиці, специфіки використання різних вокальних технік в освітньому процесі, стилістичного вокального виконавства тощо.

Науковці акцентують увагу на тому, що використання методу театралізації, передбачає здатність до акторської імпровізаційності, використання спектру позамовних засобів (мімічні рухи, жестикуляція, пластика), врахування специфіки синтезу музичних засобів і словесного вираження, акустичних ефектів, стильового виконавського обрамлення, просторове знаходження акторів-виконавців тощо. Дослідниця 
зауважує, що «театральність в музичному мистецтві може проявлятися по-різному: в драматургічному розвитку, в музично-тембровій персоніфікації, а також зовнішнім чином - як рух виконавців по сцені, візуалізація музичного образу... Активний діалог різних мистецтв може вважатися повноцінним тільки в тому випадку, якщо в ньому будуть задіяні всі аспекти театралізації: ідейний, змістовний, виразний, ілюстративний, а також враховані зовнішні фактори (акустика, костюми, сценічне оформлення), що впливають на якість контакту «сцена -зал» [7].

Ефективною формою формування сценічнообразної культури є вокально-сценічна студія, залучення до діяльності якої сприятиме створенню умов для творчої самореалізації кожного студента, розвитку його за індивідуальною освітньою траєкторією на засадах ефективної діалогічної взаємодії з викладачем, а також дозволить змоделювати соціокультурну діяльність, метою якої $\epsilon$ збереження і примноження національних традицій вокальної і сценічної майстерності. Роботу вокально-сценічної студії доцільно організовувати на основі використання технології драмо герменевтики, яка, за визначенням авторки, виявляється через інсценізацію, рольову гру та драму, характеризується активізацією творчих виконавських дій, що відображають різноманітні художні образи, їх зіставлення і взаємодію, через що формує бачення глибинних життєвих колізій, в основі яких - конфлікт, суперечності, що має наслідком перетворення буття [2]. Технологія драмогерменевтики передбачає використання ефективних форм і методів, що грунтуються на використання потенціалу драми i безпосередньо положень герменевтики, відповідно вимагає застосування інтерпретаційних умінь, акторської майстерності, вокальної техніки. Серед найбільш доцільних методів і форм - творчий проект, метод емоційної драматургії, майстерклас тощо.

Однією 3 ефективних форм роботи студії $\epsilon$ тренінг $з$ акторської майстерності. У процесі формування сценічно-образної культури майбутніх учителів музичного мистецтва у межах вокальносценічної студії доцільно проводити тренінги 3 акторської майстерності, спрямовані на розвиток музичного сприймання, візуальної дії, образної пам'яті, імпровізаційності, прийомів сценічної інтерпретації образів музичних творів. На переконання дослідниці, тренінги 3 акторської майстерності вибудовуються 3 метою пізнання природи творчості, іiі рушійних механізмів, бажання навчитися бути у творчому стані щодо навколишнього світу», тому «перш ніж навчати учнів творчості, викладачеві необхідно зрозуміти й відчути той стан, де приховані власні ресурси, знайти спосіб відкриття й поступового поповнення їх, уміння побачити свої творчі результати» [8].

У процесі виконання творчих проектів доцільно використовувати метод емоційної драматургії, що варто запропонувати майбутнім вчителям музичного мистецтва 3 метою формування їхньої сценічно-образної культури, розвитку інтерпретаційних умінь, вокальної техніки, акторської майстерності. Емоційна складова уроку з музичного мистецтва або виховного заходу передбачає ретельне планування, створення експресивного супроводу, що зумовлює зацікавленість, захопленість учнівської аудиторії музичними творами, формує відчуття причетності до здобутків національного і світового музичного мистецтва. Саме тому, зауважує вчений, метод емоційної драматургії інтерпретував як метод, за допомогою якого виконується режисура уроку, складається план до плану-конспекту - конспект сценарію виховного заходу. Залежно від підготовки кожного окремого учня й класу в цілому вчитель готує різні сценарії уроку для кожного паралельного класу. Коли в процесі вокальнохорової роботи учні показують добрі результати, співають інтонаційно чисто, виразно, дотримуються потрібного звукоутворення і звуковедення , своєчасно реагують на зауваження вчителя, не варто переривати цей вид роботи й переходити до наступного, який заплановано відповідно до плануконспекту. Доцільно продовжити роботу над шкільною піснею або хоровим твором, а на наступному уроці більше уваги приділити імпровізації або слуханню музики» [4].

\section{5. Результати дослідження}

Використання методу емоційної драматургії уроку передбачає створення творчої атмосфери зацікавленості, надає учням досвіду емоційноестетичного переживання під час опанування музичного мистецтва, сприяє відчуттю причетності до збагачення і примноження культурно-мистецького досвіду.

Ефективною формою діяльності вокальносценічної студії є майстер-класи, що сприяє унаочнення дієвості й ефективності володіння сценічнообразною культурою вчителем музичного мистецтва. Дослідниця 3-поміж вагомих ознак проведення майстер-класів виокремлює такі, як: створення умов для залучення студентів в активну діяльність; постановка проблемного завдання і вирішення його через «програвання» різних професійних ситуацій; надання можливості кожному учаснику обирати й оцінювати пропонований методичний матеріал; співпраця викладач-студент, співтворчість і спільний пошук; використання методу самостійного пізнання від загального до конкретного, від осягнення художньообразного змісту твору, загального оволодіння нотним текстом до усвідомлення художньої значущості та якісного відтворення кожної ноти; метод вибіркового опрацювання нотного тексту для визначення окремих уривків твору, метод «занурення», рефлексії» [3].

3 метою формування сценічно-образної культури майбутніх вчителів музичного мистецтва доцільно проводити майстер-класи, які розкривають праксеологічні засади використання акторської майстерності у синтезі 3 вокальною технікою у контексті інтерпретації образної системи, художньо-смислового навантаження музичних творів. У процесі проведення майстер-класів важливо демонструвати інноваційні прийоми, вокальні техніки, практикуми, які дозволяють підвищити рівень сценічної культури, вокального 
професіоналізму. Можливе використання підібраного матеріалу відеотеки, за допомогою якого можливо представити презентації досвіду колег, учителів-практиків.

\section{6. Висновки}

1. На основі теоретико-методологічного аналізу української та зарубіжної наукової літератури в даній статті дано визначення та схарактеризовано зміст освіти, на основі узагальнення практичного досвіду - проаналізовано методичні основи формування означеної якості у процесі вокальної підготовки.
2. Сценічно-образна культура являється показником концертної та виконавської практики майбутнього вчителя музичного мистецтва та музичнопедагогічної діяльності, виявляється у різних формах сценічної діяльності.

3. Обгрунтовано та розкрито найбільш досконалі та доречні форми та методи формування сценічно-образної культури в процесі вокальної підготовки, що сприяють поглибленню методичних знань, оптимізації навчального процесу, розвитку міждисциплінарних зв'язків та якісній підготовці майбутніх вчителів музичного мистецтва.

\section{Література}

1. Овчаренко Н. А. Професійна підготовка майбутніх вчителів музичного мистецтва до вокально-педагогічної діяльності: теорія та методологія: монографія. Кривий Ріг: Вид. Р. А. Козлов, 2014. 400 с.

2. Олексюк О. М., Ткач М. М., Лісун Д. В. Герменевтичний підхід у вищій мистецькій освіті: монографія. Київ: Київський ун-т ім. Б. Грінченка, 2013. 164 с.

3. Проворова Є. М. Технологія майстер-класу у методичній підготовці майбутніх учителів музики // Наукові записки. Серія: Педагогічні науки. 2017. № 157. С. 124-129. $640 \mathrm{c}$.

4. Ростовський О. Теорія і методика музичної освіти: навч.-метод. пос. Тернопіль: Навчальна книга - Богдан, 2011.

5. Гаркуша Л. І., Економова О. С. Підготовка майбутніх учителів музичного мистецтва до професійної діяльності: навч.-метод. пос. Київ: КУ імені Бориса Грінченка, 2016. 160 с.

6. Юцевич Ю. Теорія і методика розвитку співацького голосу: навч.-метод. пос. Київ: ІЗМН, 1998. 160 с.

7. Іригіна С. О. Театральна педагогіка як мистецько-педагогічна проблема у системі диригентсько-хорової підготовки майбутніх учителів-музикантів // Наукові записки. Серія: Педагогічні науки. 2017. № 157. С. 65-70.

8. Лимаренко Л. І. Студентський театр у системі професійної підготовки майбутніх педагогів: монографія. Херсон: ХДУ, 2015. 483 с.

9. Соціолого- педагогічний словник / ред. Радул В. В. Харків: Мачулін, 2015. 444 с.

10. Цзяцзюнь С. Поетапна методика формування музично-слухацької культури підлітків мультимедійними засобами // Науковий вісник Мукачівського державного університету. Серія «Педагогіка та психологія». 2018. № 1 (7). С. 154-156. doi: http://doi.org/10.31339/2413-3329-2018-1(7)-154-156

11. Шевченко І. Л. Вокальний ансамбль як форма організації музично-творчої діяльності майбутнього педагогамузиканта. Наукові записки. Серія: Педагогічні науки. 2017. № 157. С. 141-147.

12. Авксентієва С. Активні методи навчання у формуванні професійної компетентності педагога-музиканта // Проблеми підготовки сучасного вчителя. 2014. № 9 (1). С. 122-129. URL: http://www.library.udpu.org.ua/library_ files/probl_sych_vchutela/2014/9_1/Svitlana_Avksentieva.pdf

13. Горбенко О. Б. Формування художньо-інтерпретаційних умінь майбутніх учителів музичного мистецтва в оркестровому класі // Наукові записки. Серія: Педагогічні науки. 2017. № 157. С. 55-59.

14. Bond E. Notes on Theatre in education. The Hidden Plot. London: Methuen, 2000. 221 p. doi: http://doi.org/10.5040/9781408164303

Received date 18.09.2019

Accepted date 17.10.2019

Published date 30.11.2019

Косінська Наталія Леонідівна, аспірант, кафедра теорії та методики музичного мистецтва, Інститут мистецтв Київського університету імені Бориса Грінченка, бул. І. Шамо, 18/2, м. Київ, Україна, 02152 , викладач,Університетський коледж Київського університету імені Бориса Грінченка, пр. Гагаріна, 16, м. Київ, Україна, 02094 